\title{
1. Introduction to the Handbook of Translocal Development and Global Mobilities
}

\author{
Guus van Westen, Maggi Leung, Kei Otsuki and \\ Annelies Zoomers
}

\section{INTRODUCTION}

When the coronavirus hit the world end of 2019, something happened that had not been observed in previous pandemics. Media coverage of the pandemic has exceeded the attention given to any other virus outbreak. This can be explained by the unprecedented scale of the disease, but arguably also because it squarely hit the self-centred core areas of the world: East Asia, Europe and North America. Furthermore, media attention has focused not just on the health impact and its human toll, but at least as much on the widespread 'lockdowns' imposed by governments in many countries in attempts to contain the spread of the virus. The pandemic virtually froze the world, immobilising what had become a global society based on flows: flows of people, of finance and capital, of merchandise and of information; flows that had become the defining features of the world of globalisation. The unprecedented feature was that the immobilisation of these flows seemed the real issue at stake in the pandemic, and that its cause, the health crisis due to the spread of a new virus, was the lesser issue of the two.

At the time of writing, the true impact of COVID-19 is far from clear, but serious repercussions have been reported from across the globe. While the richer countries have been first-hit in relative terms - this due to their prominent involvement in global exchanges - it is clear that increases in the number of people being thrown into absolute poverty will be highest in low-income countries (IMF 2020). Unlike their counterparts in wealthier countries, vendors, craftspeople and people working in all sorts of local service activities in the Global South have little to no savings and cannot afford to remain home. Without a buffer or support scheme, they have to get out to make a living in markets, street-side shops and other places with often high levels of exposure to others and therefore risk of infection. This, admittedly, would have been the same in quarantine conditions imposed in the past. But now, much of the food and merchandise needs to be brought in from elsewhere, often over long distances. From the production side, much of the new employment linked to recent economic growth has been in industries of the networked economy of globalisation, be it garment workers in factories working for export or cleaners and waiters in 
tourism establishments. They suffer directly as a consequence of the collapse of the majority of mobility flows.

\section{TRANSLOCAL FLOWS}

Thus COVID-19 shows how our world has been transformed in recent decades. Connections to other places have become a key feature in defining a locality in terms of its economic and social performance, arguably even more so than the characteristics of the locality. Manuel Castells, the Catalan sociologist who greatly contributed to our understanding of globalisation, first elaborated this change in the 1990s, when he contrasted the role of the 'space of flows' - that is, the connections in terms of travel by people, and flows of capital and merchandise, and of knowledge and ideas - in shaping the fate of any locality, with the declining role of the 'space of place'; that is, the physical and other in-situ characteristics of that place. In a globalising world, what matters in the first place is the nature of these translocal links connecting people, communities and places with others far and close. Being included in 'global' networks of economic activity, finance, travel, political power and knowledge is a prerequisite of local development. But the terms of inclusion - that is, the position of people, communities, localities, in such translocal networks - are important. To a greater or lesser degree, places and communities across the globe have moved along this path of networked local development, where flows and connections through space and between levels of scale shape the nature of local transformations.

To be sure, globalisation has created opportunities for development: the global shift of much of manufacturing and some service industries to countries such as China, India, Mexico and Turkey has literally lifted hundreds of millions of people out of debilitating poverty. Worldwide progress in education, health and human longevity over the last half century is impressive. These successes have been achieved at the cost of several drawbacks, however. One is increasing inequality that is intrinsically linked to the model of neoliberal deregulation dominating the global political economy. 'Winner takes all' is almost literally the case in some new industries, such as computer software, where frontrunners set standards (think of Microsoft, Google, Facebook) that turn them into monopolists. This principle has become more mainstream as global market integration means that people with few marketable assets or skills have to compete with others worldwide, while people with assets that are high in demand can benefit from the best opportunities globally. Socio-economic inequalities have reached levels where they effectively undermine human development, as most forcefully argued by French economist Thomas Piketty $(2014,2019)$. Beyond inequality, the coronavirus crisis made us more aware of our vulnerability and the many insecurities on which our lives are built. The global economy has built on a development model that hinges on flows and connections while the reality of crises - pandemics, political or economic shocks, ecological limits - impose borders and renewed territorialisation. Beyond this clash of systemic interdependence and mobility with the resurgence of delimitation and territory, we are more than ever 
confronted with planetary boundaries (Rockström 2015). In fact, the spread of new viruses may be linked to massive human encroachment on the natural environment - an aspect that has hitherto captured little attention. Human-induced climate change undercuts the sustainability of the status quo development model that thrives on growth and expansion of resource use. As Bruno Latour (2017: 16) pointed out, focusing on the politics of the new climate regime, 'the planet is much too narrow and limited for the globe of globalization; at the same time, it is too big, infinitely too large, too active, too complex, to remain within the narrow and limited borders of any locality whatsoever'.

\section{TRANSLOCAL DEVELOPMENT}

This Handbook of Translocal Development and Global Mobilities aims to review how local development has been shaped by global flows (and 'lockdowns'), while offering a new framework for understanding the implications for local people's livelihoods and wellbeing. In searching for (new) ways to improve local livelihoods - and achieve the Sustainable Development Goals (SDGs) with the motto of 'leaving no one behind' - we start from the idea that the flows of capital and flows of people will play a key role in shaping people's livelihoods opportunities. The opportunity to benefit from investment and mobility, and the constraints imposed by such flows or being excluded from or trapped in networks, will bear heavily on the future. In addition to large-scale foreign and domestic investments, the scope for development is further shaped by other money flows, ranging from remittances and traditional donor money (Official Development Assistance), but also money originating from the BRIC countries (Brazil, Russia, India, China) and new charities (for example, the Bill and Melinda Gates Foundation), to a growing network of social businesses and impact investors. While recent decades have seen rapid increases in the total volume and diversity of capital flows, these can, however, no longer be taken for granted. The post-coronavirus world is an arena of conflicting trends, with some pushing for continued openness and integration while others backtrack from the fluid world of globalisation in search of localisation and renewed territorial control.

Discussing the construction of space and spatial differences, Doreen Massey (2005) likened the effects of flows of capital to the layers of sediments rivers leave in the landscape. Just like geological sedimentation, successive waves of investment deposit production capacity, infrastructure and other assets in particular places that fit the needs and opportunities of a particular period. Most strikingly, though, investment favours existing concentrations of people and assets; that is, the power and sunk investment anchored in particular in metropolitan centres. With the exception of harvesting natural resources (agriculture, mining), nearly all economic activity benefits from close proximity to markets, suppliers, knowledge, workers and infrastructure. But changing circumstances also channel investment to new places. Recent years have seen the rise of new hubs: places where new investments and newcomers concentrate, with direct implications for the livelihood opportunities of 
'local' groups - targeted beneficiaries, but also bypassed people - inside and outside. Such investment and settlement hubs are often conflictive in the sense of generating competing claims between different groups, creating new opportunities for some and attracting migrants, while also displacing others, forcing them to move and seek resettlement in other places. The inflow or outflow of capital (and, more particularly, large-scale land-based investments, or investment in other natural resources) has enormous implications for the livelihood opportunities of local groups, not only for directly affected populations in the investment hub, but also for successive waves of others. The effects will travel in space, creating ripple effects or chains of translocal effects which also affect people in bypassed places: people are triggered to move and resettle in nearby or faraway places, or are confronted with the arrival of displaced groups, which may lead to competing claims but can also generate new opportunities.

Large-scale capital investment and migration are very much interconnected, and should not be analysed in isolation. In addition to the link mentioned between capital flows and (im)migration, displacement and resettlement, diasporas but also individual migrants often play a direct role by investing in their home communities or nearby cities. They may also open the door for domestic and foreign investors and trigger new flows of commodities (trade), knowledge and ideas. As a consequence of the emergence of new flows of capital and people, global landscapes are undergoing rapid transformations. Traditional North-South relations have given way to a more diverse and multi-polar pattern in which South-South, South-North and NorthSouth exchanges play their roles. Large-scale flows of people and capital investments have direct consequences for 'local' people's livelihood opportunities. These flows are responsible for much of the 'development' we witness taking place in different localities.

The link between capital and people flows is very controversial. As a consequence of global investment and migration (including repatriation) policies, many people are limited in their freedom to stay, or forced to move (Zoomers, Leung and Van Westen 2016). Taking into account this reality (and accepting the new SDGs as the new universal agenda for action), the question is how to steer flows of capital and flows of people in the direction of inclusive and sustainable development.

\section{THIS HANDBOOK}

This handbook aims to contribute to a better understanding of the link between large-scale flows of capital/people and 'inclusive development'. Given current dynamics of capital investment and migration, what kind of mobilities are taking place, and in what direction? What are the new geographies of development, and what are the consequences of the moving in and moving out of capital/people (including goods and ideas) for 'local' development and achieving the various SDGs?

More theoretically, we argue that flows and circulations of capital and people merit a more central place in theorisation about development. 'The so-called mobilities turn in social science has undoubtedly been of major significance in challenging 
the sedentarist assumptions embedded in much social thought' (Sheller and Urry 2006; Walters 2014: 4), but this is often not reflected in discussions about 'local' development. Globalisation, in alternation with waves of de-globalisation and re-territorialisation, has given rise to new and intensified flows and circulations that will shape places, development trajectories and livelihood possibilities in distinct ways. Local development plays out not just in fixed settings, but is increasingly shaped by the way people are attached to and participate in networks. Rather than looking at 'local development' in terms of local people having access to and control of 'local resources', we acknowledge the importance of 'networked space' and positionality (Zoomers, Leung and Van Westen 2016). Given the rapid transformations, accepted notions such as 'development as freedom' (Sen 1999) are increasingly under pressure. Sen is credited for emphasising a human focus on 'development', defining it as 'the promotion of overall freedoms of people to lead the kind of lives they have reason to value' (Sen 1999: 10). This was instrumental in overcoming a narrow focus on development as economic growth and structural transformation till the 1990s, which highlighted processes of change rather than linking to meaningful outcomes for people. But there is an increasing gap between this ideal of steadily removing limitations to individual choice, and a reality of growing constraints and vulnerabilities imposed on people's real-life options. We need to better understand the link between wellbeing and the new types of flow-driven developments from outside, without downplaying the agency of individuals and groups.

In practical terms, development is now generally seen in terms of the 17 SDGs adopted within the framework of the United Nations in 2015 for the period to 2030 . The SDGs cover key global objectives without a unifying concept underpinning them, and some are actually not easily aligned - take, for instance, the tension between SDG8 (decent work and economic growth) and environmental objectives such as SDG13 (climate action). This is inevitable as the Goals result from negotiations among governments with very different perspectives and priorities. Nevertheless, the SDGs have considerable near-universal support, with the added benefit of offering operational guidance with their 169 targets and 232 individual indicators. The latter at the very least contribute to our grasp of the state of global society as these statistics become more available and better thanks to their newly acquired status. The SDGs themselves can be seen as a flow of policy from the global level to countries around the world, uniting them in their diversity. While sharing the Goals and the accompanying slogan of 'leaving no one behind', there is a need for a conceptual update on how people and communities can benefit from new types of flow-driven development, plug in the relevant flows and mitigate undesirable effects. Meanwhile, the pandemic and the ensuing economic downturn also imply a threat to the pursuit of the SDGs. The enormous costs involved in overcoming the crisis mean that less is available for investment in attaining the SDGs. Transformations towards a more inclusive and sustainable society are both more needed and more difficult to realise as a result. Health, climate change adaptation and social justice are all indispensable and should be tackled with an integrated agenda, not competing ones. 
This handbook sets out to do this by means of the concept of translocal development. This implies a relational perspective on human development, constructed through flows and links between people, institutions and localities. The interactions of actors conducted in networked space are non-linear and multidirectional, and also multi-scalar (Freitag and Von Oppen 2010). This means that there need not be a direct causal link between flows and their effects, that causality of influence may travel in different directions, and that different levels of scale (say, international agreements, national policy, individual behaviour) are linked, but not in predefined ways. Local human development is best seen as a system, typically a complex system in the sense that many variables (connections, actor initiatives) play a role in ways that cannot always confidently be predicted, as both actions taken and their consequences may vary according to different sets of circumstances. That does not mean patterns cannot be observed. Repeat behaviour creates structures, which in turn guides further behaviour (agency) in certain directions, though without actually fixing it - alternatives are possible. Translocal development should therefore be construed as a complex outcome of agency within local and wider networks.

Translocal development highlights the role of external relations but does not deny the importance of 'the local'. Not only can local agency be decisive, but what also matters is how different subsystems share a particular space or 'landscape'. The landscape approach focuses on how changes in one system may clash with others in a particular geographical setting, or alternatively may cascade into dynamic effects. For instance, export opportunities for a local crop may encourage large-scale expansion of production, at the detriment of environmental conditions or displacing the use of land resources by less powerful groups than the export farmers. Thus, the systems approach favoured in translocal development tries to view external influences as well as knock-on effects in other domains locally; it recognises the structural role of links while having an open eye for agency.

In development studies, and especially in livelihood research, considerable attention has long been given to local people's agency and the importance of capitals and capabilities (Bebbington 1999; de Haan \& Zoomers 2005; Kaag et al. 2004). Seen from this perspective, people make their own choices in building their livelihood by making use of the different kinds of capital they can mobilise: human capital (labour, skills) and natural capital (land, water) are important assets, together with financial and physical capital (tools, equipment, buildings), social capital (for example, networks of relatives and friends) and, lastly, cultural capital (norms and values, and so on). In the world of networked globalisation of the twenty-first century, however, it is clear that people's agency is increasingly under pressure. Whether or not people are capable of benefiting from global flows cannot be understood in local terms of agency or capital stock available. Opportunity structures depend on decisions by outsiders, and whether people can link up with the right networks, and under what terms. Moreover, the set of capitals people need is no longer the same. Development is increasingly about protecting local capital from appropriation by others or from de-capitalisation, as in becoming obsolete because of competing options. People not only need to be able to do a job well enough, but must also compete with distant 
others under different conditions (including at the household level). Competing often involves being able to 'link up', gaining access to information and making timely decisions. Development is also increasingly about whether or not people are capable of dealing with the unexpected and with extremes, and being resilient not only in response to climate variability, but also socially and economically. Instead of focusing on 'meeting local demands', the emphasis in current discussions is on fulfilling expectations and fulfilling promises (that is, that businesses and migrants keep their word; see Schapendonk 2014). What these bring about is not necessarily the type of development to which people aspire. This handbook aims to push forward the old school of livelihood-approach thinking and offer new frameworks.

\section{CONTRIBUTIONS}

In order to analyse the link between different types of capital/people flows and inclusive development, we pay particular attention to the following domains: large-scale investments in land for food and biofuels; large-scale investments in nature conservation and REDD+ (reducing emissions from deforestation and forest degradation); large-scale investment in urban development and infrastructure expansion; flows of remittances/tourist spending in relation to different types of mobilities; and the developmental impact of different types of donor money/impact investments. In assessing the implications for inclusive development, the chapters will focus on strategies by local groups to 'link up' (or 'become linked') and share benefits. In doing this, explicit attention will be given to the fact that development increasingly comes from the outside. We have a special interest in better understanding of the complex link between 'locals' (or 'natives'), on the one hand, and outsiders (or 'foreigners', including new categories of returnees), on the other.

This book is composed of 15 chapters, each of these focusing on particular types of people/capital flows and having particular dynamics on the ground with implications for translocal relations and livelihoods.

The first part (chapters 2, 3 and 4) analyses development from a flows-of-people perspective, focusing on 'migratory landscapes' with people flowing in and out, dependent on opportunity structures and border regimes, and producing flows of remittances. It shows how mobility of people is a 'normal' or at least very functional part of local livelihoods, facilitating people to combine the best from various places while minimising risks, showing the role of migration as a livelihood capital (in addition to social, physical, financial and other types of capitals) and making people more flexible and less vulnerable.

Nanneke Winters, Griet Steel and Carlos Sosa (Chapter 2) bring our attention to Nicaragua (with a continuous flow of people moving forward and backward to Costa Rica and the US), where temporary migration helps men and women to achieve socio-economic improvement in their home community. In turn, these strategies result in development corridors between people and places. After this, Ingrid Boas (Chapter 3) illustrates how in Bangladesh people responding to extreme levels of 
climate variability are continuously on the move, sometimes as a conscious ex ante strategy, but also in response to emergencies; she also analyses the role of mobile technologies in how people move, showing that this has not contributed to a drastic shift of social networks. Rather, the networks often remain the same, but technology helps in enabling mobility in a more coordinated manner, making mobility decisions more effective and communities more resilient. This is followed by a chapter by Joris Schapendonk (Chapter 4), who, by zooming into migration between sub-Saharan Africa and Europe, points to the fact that migration is increasingly blocked and that it is increasingly difficult to speak about 'migration flows'. As a consequence of large-scale investments in border surveillance and anti-migration policies, people are increasingly hindered in their migration trajectories, while migration industries are playing active roles in helping people to overcome hurdles. This often goes hand in hand with exploitation and new vulnerabilities. Many migrants are stuck and/or have to deal with danger and risks. Migration is increasingly 'bumpy', as is being illustrated by experiences from the Gambia.

After this, the second part (chapters 5 to 8 ) analyses local development processes from the perspective of different types of capital flows, making a distinction between different types of landscapes.

First, large-scale investments are being made in value chain development and agribusiness, often with irrigation and going hand in hand with the expansion of cultivated areas.

In Chapter 5, Guus van Westen shows how worldwide food production is increasingly organised in global value chains, linking producers, traders, processors and consumers in distant localities. Inserting smallholders in poor countries into corporate value chains by means of inclusive business models has become a major development strategy, aiming not only for just and sustainable agricultural growth, but even for further goals such as food security. While outcomes in terms of farmer incomes can be positive, there are also risks involved in this approach, certainly when private-sector-led initiatives are expected to deliver development objectives beyond production increase and the interests of those involved in the business model and value chain. Examples draw on current research in sub-Saharan Africa.

Sebastiaan Soeters, Ruben Weesie and Annelies Zoomers (Chapter 6) show how in Ghana private sector investments in the agro sector have rapidly increased; even though this might contribute to the increased wellbeing of some farmers locally, it soon translates into rapidly increasing flocks and expansion of the cultivated areas, followed by new conflicts, especially between the farmers and pastoralists who are increasingly blocked and can no longer access traditional commons. Janwillem Liebrand, Wouter Beekman, Chris de Bont and Gert Jan Veldwisch (Chapter 7) demonstrate the fact that in spite of large investment in top-down large-scale irrigation schemes, bottom-up and farmers-driven irrigation should not be underestimated, often inducing multiple impulses to local development, and often being much more productive than large-scale irrigation. In Chapter 8, Alberto Alonso-Fradejas focuses on the translocal effects of large-scale investment in cane and palm complexes in Guatemala. He shows that many of these investments come with promises on 
development, while they are also the drivers of chains of 'impairing destruction', going hand in hand with destruction of landscapes and processes of expropriation and displacement.

In addition, simultaneously with the expansion of cultivated areas, large-scale investments are also made in areas for nature conservation and wildlife conservation (often in the form of parks and reserves); and, oppositely, large-scale mining (LSM; leading to resettlement and destruction of landscapes). Marja Spierenburg (Chapter 9) brings forth the consequences of the upsurge in investments in nature conservation and wildlife conservation, including land restoration and REDD+, showing the emergence of an 'environmentalists' paradox'; that is, human wellbeing in areas with high rates of biodiversity is lower than in areas with degraded ecosystems. While premised on promises to increase human wellbeing, investments in nature conservation are reshaping spaces, creating new forms of enclosure and exclusion, privatising nature and turning it into a commodity. Focusing on investments in wildlife ranching in South Africa, she shows the consequences for local groups, whose manoeuvring space is increasingly limited. Kei Otsuki (Chapter 10) further explores translocal effects of the Limpopo National Park in Mozambique by analysing one of the largest conservation-induced resettlement schemes in southern Africa. The chapter highlights that much of the discussions focus on the sustainability of the national park and the problem of the enclosure, and displacement and resettlement is usually considered to be a solution. The chapter shows that the sustainability of resettlement is not guaranteed because of the ripple effects after people are resettled and a new built environment emerges at the edge of the conservation area. Therefore, sustainability of resettlements requires more attention.

Chris Huggins (Chapter 11) and Marjo de Theije (Chapter 12) analyse the local dynamics triggered by investment in mining and resources exploitation/landscape destruction. Chris Huggins underlines the importance of flows of capital and people in the global mining sector for countries like Tanzania, making the distinction between LSM by transnational corporations (with small 'expatriate' workforces) and artisanal and small-scale mining (ASM), which, conversely, involves a large number of workers, who often migrate within state borders towards new mining opportunities. Commodities originating from ASM are usually informally traded, resulting in 'illicit' and 'invisible' material and financial flows and development chains. Over the last decade, several African states have attempted to regulate LSM capital flows to maximise government revenues, and adopted local content policies to benefit local businesses. Simultaneously, states are trying to 'formalise' ASM production and commodity chains. Marjo de Theije focuses on the link between local development (in Suriname) and the Brazilian-driven business of gold mining, showing the multiple controversies in the meaning of 'local' development. Also in Suriname, the extraction of gold can take diverse shapes, from large-scale mines operated by multinational companies, to junior corporations that focus on the exploration of mineral resources, to a variety of small-scale and artisanal gold-mining activities. In some cases, these different modalities of gold mining co-exist in complementarity, while in other contexts they clash and enter into long-lasting conflicts. Large 
mining companies are present in different countries, and their skilled labour force travels between the operations. Small-scale gold mining brings many more miners on the move, typically unskilled workers who live in poverty and have few other opportunities to improve their economic situation. Finally, Joanny Bélair and Thabit Jacob (Chapter 13) explore the positionality of civil society organisations (CSOs) in initiatives to make investments in land and mining more inclusive. They analyse the subject at both the national (influencing policy) and local (empowerment) level. Their findings underline the importance of local context in steering the scope and outcomes of civil society initiatives. The rise of civil society movements as such can be seen as a translocal flow of ideas and organisation models spreading around much of the globe and being reinterpreted locally. The realities of operating in Tanzania, the locus of Bélair and Jacob's case study, is that CSOs have to balance a difficult position between the need for foreign resources (funding) and local priorities, while on the ground their room for manoeuvring is constrained by having to balance donor expectations, their position nationally as legitimate partners in development debates and the perspectives of local communities that are not necessarily aligned.

The final part focuses on urbanising landscapes, analysing the developmental impact of flows of capital - investments in new city development and urban infrastructures. Femke van Noorloos (Chapter 14) focuses on the fact that nowadays, consortia of investors, developers and architects, sometimes in collaboration with national governments, have across Africa introduced large numbers of new utopian urban mega-projects or 'new cities'. She critically analyses the effects of such investments, showing (using the case of Konza Techno City in Kenya) that such new cities pose severe risks to inclusive urban development as formulated in SDG11. She shows that one of the main problems of new cities lies in the failure to accept 'informal' development as being an intrinsic part of African cities. Pre-existing activities, humans and livelihoods start to change and co-evolve as soon as an idea for a new city is elaborated, but vulnerable groups are often excluded from the benefits.

This is followed by Murtah Shannon (Chapter 15) on the emergence of 'donor cities', focusing on the case of Beira (Mozambique). Although investment in infrastructure development is widely recognised as being crucial to sustainable urban development, it is also coming with contra-productive types of development; for example, development-induced displacement. He shows how in Beira - a hotspot of international infrastructure investments and regarded by donors as an example of successful urban development - global investments have instigated chains of displacement, with far-reaching implications for urban sustainability which have been excluded from the city's development narrative.

These chapters are followed by a conclusion. In making a distinction between different types of stakeholders, we try to learn lessons about how to move in the direction of inclusive and sustainable development. 


\section{REFERENCES}

Bebbington, A. (1999) Capitals and capabilities: a framework for analysing peasant viability, rural livelihoods and poverty. World Development, 27(12), 2021-2044.

Castells, M. (1996) The Rise of the Network Society: Part 1 of The Information Age: Economy, Society, and Culture. Chichester: Wiley.

Freitag, U., and A. von Oppen (eds) (2010) Translocality: The Study of Globalising Processes from a Southern Perspective. Leiden: Brill.

Haan, L. de, and A. Zoomers (2005) Exploring the frontier of livelihoods research. Development \& Change, 36(1), 27-47. doi:10.1111/j.0012-155X.2005.00401.x.

IMF (International Monetary Fund) (2020) World Economic Outlook: The Great Lockdown. Washington, DC: IMF.

Kaag, M., R. Van Berkel, J. Brons, M. De Bruijn, J. W. M. Van Dijk, L. De Haan, G. Nooteboom, and A. Zoomers (2004) Ways forward in livelihood research. In Kalb, D., W. Pansters and H. Siebers (eds), Globalization \& Development: Themes and Concepts in Current Research (pp. 49-74). Dordrecht: Springer.

Latour, B. (2017) Facing Gaia: Eight Lectures on the New Climatic Regime. Cambridge: Polity Press.

Massey, D. (2005) For Space. London: Sage.

Piketty, T. (2014) Capital in the Twenty-First Century. Cambridge, MA: Harvard University Press.

Piketty, T. (2019) Capital and Ideology. Cambridge, MA: Harvard University Press.

Rockström, J. (2015) Big World, Small Planet: Abundance within Planetary Boundaries. New Haven, CT: Yale University Press.

Schapendonk, J. (2014) What if networks move? Dynamic social networking in the context of African migration to Europe. Population, Space and Place, 21(8), 809-819.

Sen, A. (1999) Development as Freedom. New York, NY: Anchor.

Sheller, M., and J. Urry (2006) The new mobilities paradigm. Environment and Planning A: Economy and Space, 38(2), 207-226.

Walters, W. (2014) Migration, vehicles and politics: three theses on viapolitics. European Journal of Social Theory, 18(4). doi:10.1177/1368431014554859.

Zoomers, A., M. Leung and A. van Westen (2016) Local development in the context of global migration and the global land rush: the need for a conceptual update. Geography Compass, 10(2), 56-66. https://doi.org/10.1111/gec3.12258. 